\title{
Evolutionary classification of the Upper Cretaceous (Turonian-lower Campanian) planktic foraminifera with incipient meridional ornamentation
}

\author{
M. DAN GEORGESCU \\ Department of Geoscience, University of Calgary 2500 University Drive NW, Calgary, Alberta T2N 1N4, Canada \\ (e-mail: dgeorge@ucalgary.ca)
}

\begin{abstract}
A new genus, Fingeria, is recognized among the globular-chambered trochospiral planktic foraminifera of the Upper Cretaceous (upper Cenomanian-lower Campanian). It consists of two pre-existing species: F. loetterlei (Nauss, 1947) and F. kingi (Trujillo, 1960). The ornamentation consists of scattered pustules, which can often fuse to form rugosities and, occasionally, costellae, especially over the earlier chambers of the test. Meridional ornamentation pattern is occasionally developed over isolated chambers. Fingeria is the only lineage of the whiteinellid stock that exhibits ornamentation coarsening and preferential orientation, which can be meridional or parallel to the periphery. J. Micropalaeontol. 29(2): 149-161, December 2010.
\end{abstract}

KEYWORDS: planktic foraminifera, taxonomy, Upper Cretaceous, evolutionary classification, Fingeria new genus

\section{INTRODUCTION}

The process of developing an evolutionary classification framework for the Cretaceous planktic foraminifera requires high resolution observations on the test morphology in stratigraphical context and continuous re-evaluation and improvement of the operating concepts (e.g. taxon definition, etc.). Steineck \& Fleisher (1978) demonstrated that convergence and iterative evolution are the dominant patterns in the Cenozoic planktonic foraminiferal evolution. The existence of these patterns in the Cretaceous planktics was demonstrated in a number of studies based on high detail test morphology (Georgescu \& Huber, 2006, 2008, 2009; Georgescu, 2007; 2009a, b, c; 2010a, b; Georgescu \& Abramovich, 2008a, b, 2009; Georgescu et al., 2009). The effects of recognizing such processes in Cretaceous planktic foraminiferal evolution became apparent in the classification approach used in group taxonomy. Evolutionary classification, which can be developed through the application of classical evolutionary methods, can provide a method to group species into higher units according to inferred ancestordescendant relationships.

Developing an evolutionary classification framework is a challenging process, partly due to the existence of a single taxonomical method (i.e. typology) for more than 250 years. According to the fundamental principle of this time-honoured method, the units at any rank are grouped into units of higher rank according to morphological resemblances between them. The practice resulted in groups that are based on a relatively small number of features, which were often developed through convergent and/or iterative evolution. Therefore, the vast majority of the typological units are artificial (polyphyletic and paraphyletic). Phylogenetic classification was proposed as an alternative to the typological classification by Hennig (1950; 1966). In contrast to the typological approach, phylogenetic classification takes into account the ancestor-descendant relationships between the various taxonomical units (e.g. species, genera), but the influences of the time factor as reflected in the fossil and stratigraphical records play a rather minor role in taxa grouping at any hierarchical level. As a result, few specialists adopted it as a working method. A possible explanation for the lack of success in developing an alternative classification to the typological one is that all the phylogenetic classification framework attempts were entirely based on typological, Linnaean taxa, which have little likelihood of representing natural units (Georgescu, 2009c; 2010a, b).

A first step in developing an evolutionary classification for the Cretaceous planktic foraminifera was the critical review of the species concept used in taxonomical studies and current practice. The necessity to re-evaluate the species concept was primarily generated by the inadequacy of the extensively used morphospecies concept in accommodating species variability. The composite palaeontological species was defined by Georgescu \& Huber $(2007,2009)$ in order to recognize species as natural units, whose existence is observed directly in the fossil and stratigraphical record.

A composite paleontological species is the basic unit with taxonomic significance in the fossil record, and has the following characteristics: (1) it is monophyletic; (2) it has a distinct range of morphological variability, showing relative stability over a definable period of time and presenting relatively discrete evolutionary changes; (3) it is a morphologically heterogeneous and discontinuous entity, consisting of one or (mostly) more morphological and/or paleoecological varieties; (4) it has its own and continuous developmental history traceable in space and time, which can be directly derived from the fossil record; and (5) its existence and integrity can be tested not only by comparative morphological distinctiveness, but also by its response to paleoenvironmental and geological factors (e.g., paleoclimatic changes, sea level fluctuations), as inferred from paleontology and related geological disciplines (Georgescu \& Huber, 2009, p. 360).

Species grouping into higher-level units strongly depends on the classification approach. In the typological approach species are grouped into genera according to their morphological resemblances; the degree of resemblance is determined by a relatively small number of features, which are considered of taxonomical 


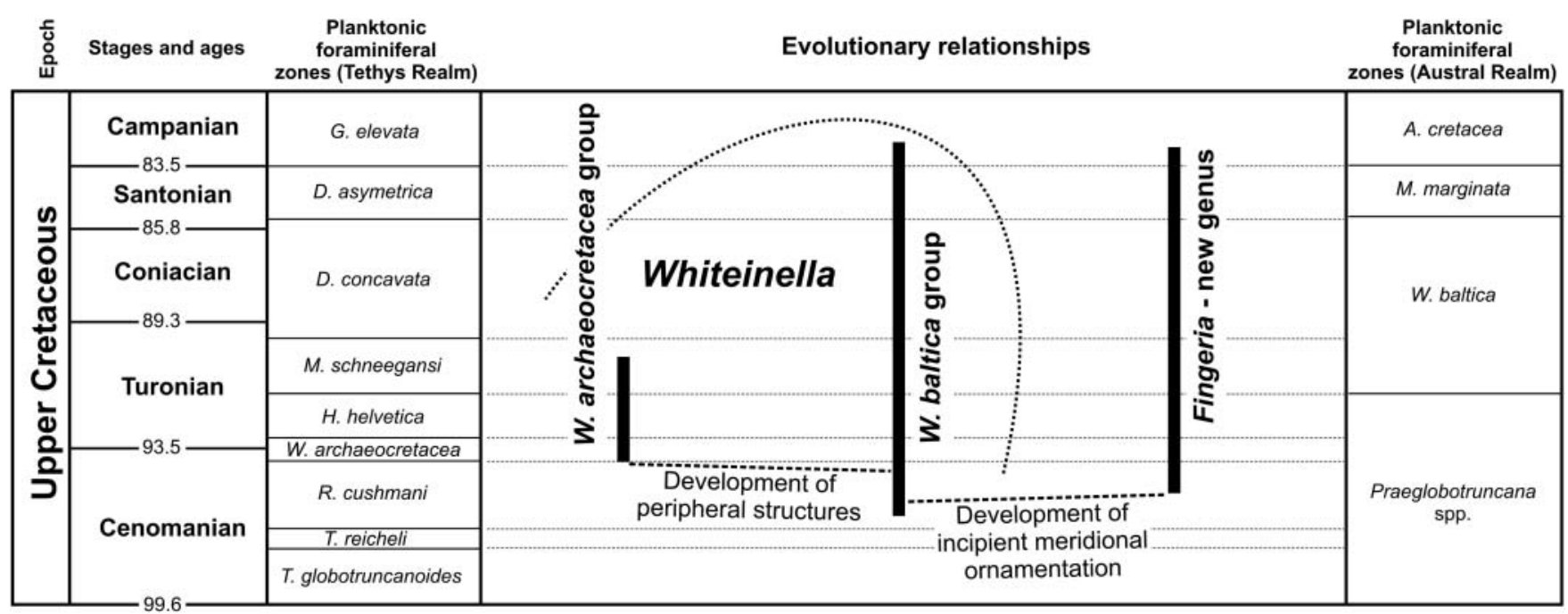

Fig. 1. Diagram presenting the three groups of whiteinellid species, their stratigraphical distribution and inferred evolutionary relationships. Tethyan Realm biozonation is after Robaszynski \& Caron (1995), Austral Realm zonation after Huber (1992) and ages after Gradstein et al. (2004). Abbreviations: A., Archaeoglobigerina; D., Dicarinella; G., Globotruncanita; H., Helvetoglobotruncana; M., Marginotruncana; R., Rotalipora; T., Thalmanninella; $W$. , Whiteinella.

significance. Evolutionary classification is fundamentally different and a taxonomist using this approach will group species into higher units (i.e. lineages) based on a mixture of morphological resemblances resulting from common ancestry and differences resulting from evolutionary changes (Georgescu, 2009c; 2010b). Therefore, the higher units have a dynamic sense in evolutionary classification whereas in typology the units are rather static. The lineage as a taxonomical unit in evolutionary classification was defined by Georgescu (2009c, p. 264) as follows:

... a monophyletic taxonomic unit with significance in evolutionary classification, situated immediately above the species level, representing a grouping of species based on the phylogenetical relationships between them, having a distinct evolutionary history in space and time that can be reconstructed from the fossil and stratigraphic record and is separated by morphological gaps from other similar units.

Whiteinella Pessagno, 1967 (type species: $W$. archaeocretacea Pessagno, 1967) was created to accommodate middle Cenomanian-lower Campanian globular-chambered planktic foraminifera with a broadly rounded periphery, umbilicalextraumbilical aperture bordered by a flap and ornamentation consisting of relatively large scattered pustules, resulting in a spinose appearance. The genus was reviewed by Robaszynski \& Caron (1979), who included within it the following species: W. aprica (Loeblich \& Tappan, 1961), W. archaeocretacea, W. baltica Douglas \& Rankin, 1969, W. brittonensis (Loeblich \& Tappan, 1961) and W. paradubia (Sigal, 1952). This revision was widely accepted. The origin of Whiteinella was considered to have been among the globular-chambered Hedbergella Brönnimann \& Brown, 1958 (Caron, 1983; Hart, 1999; Hart et al., 2002).

The polyphyletic nature of Whiteinella was demonstrated with the taxonomic revision of Anaticinella Eicher, 1973 (Georgescu, 2010a). Anaticinella was redefined in an evolution- ary classification to accommodate a late Albian-early Turonian lineage that gradually develops a faint peripheral keel, complex umbilical system consisting of portici and ornamentation exhibiting fused pustules and, occasionally, vermicular structures in the terminal species. A significant outcome of this study is that it demonstrated that the whiteinellid stage of this lineage is transitional from the hedbergellid stage to the anaticinellid one. Moreover, the study demonstrated the necessity of a higher accuracy in evaluating the taxonomical significance of detailed morphological features (e.g. ornamentation elements and their distribution, pore characteristics, etc.).

Three groups of species can be recognized among the Whiteinella representatives, excepting A. aprica, based on high resolution morphological features (Fig. 1). Whiteinella baltica group of species apparently represents the stem of the whiteinellid group, with the first evolutionary occurrence in the late Cenomanian (Rotalipora cushmani Biozone) and having generalized features, such as globular chambers, broad periphery without peripheral structures and ornamentation consisting of scattered pustules. This group includes $W$. baltica, $W$. brittonensis and W. paradubia. The Whiteinella archaeocretacea group, which includes $W$. archaeocretacea and, probably, $W$. inornata, evolved in the latest Cenomanian with the development of a subangular periphery and incipient peripheral structures comprised of agglomerated pustules. Globular-chambered trochospiral planktic foraminifera with incipient meridional ornamentation are defined herein as a new lineage developed in a new genus, Fingeria. It consists of two composite palaeontological species, F. loetterlei (Nauss, 1947) and F. kingi (Trujillo, 1960), which never received senior species status in the past in any of the taxonomical reviews based on typological principles (Masters, 1977; Robaszynski \& Caron, 1979; Caron, 1985).

\section{MATERIAL PROVENANCE}

The material studied was collected from Turonian-lower Campanian sediments drilled at two Deep Sea Drilling Project 
(DSDP) sites: 95 (Yucatan outer shelf, offshore Mexico, Caribbean region) and 463 (Mid-Pacific Mountains, equatorial Central Pacific Ocean). Most of the samples were made available at request by the DSDP/Ocean Drilling Program (ODP)/ Integrated Ocean Drilling Program (IODP) headquarters. Additional samples from the two sites were examined in the Ocean Micropaleontology Collection (OMC) at the National Museum of Natural History (NMNH), Smithsonian Institution, Washington D.C. Samples are labelled according to the DSDP/ ODP/IODP standards as follows: leg number-site number-core number-section, sample depth in centimetres.

A collection of four species was studied in the Cushman Collection: Hedbergella murphyi Marianos \& Zingula, 1966 (USNM 641539), Archaeoglobigerina bosquensis Pessagno, 1967 (USNM 689281) and Hedbergella bornholmensis Douglas \& Rankin, 1969 (USNM 464651) and from the University of California Museum of Paleontology, Berkeley: Globigerina loetterlei Nauss, 1947 (UCMP48788); the environmental scanning electron microscope (ESEM) micrographs of the Cushman Collection specimens were illustrated online by the Mesozoic Planktonic Foraminifera Working Group (2006). Newly taken ESEM micrographs of the holotypes of Rugoglobigerina kingi Trujillo, 1960 (UCMP 26678) and Hedbergella hansbollii Trujillo, 1960 (UCMP 26676) deposited in the University of California Museum of Paleontology were also examined. In addition, topotype material of Rugoglobigerina plana Belford, 1960 from the lower Santonian Toolonga Calcilutite of Western Australia was studied in the NMNH collections.

Most of the material of this study was collected from the sediments from DSDP Site 463 (Fig. 2). The preservation at this site is very good in most of the 23 samples studied; although tests are recrystallized, many of them preserve the delicate periapertural structures and test ornamentation. Fingeria kingi and $F$. loetterlei occur at this site in the Turonian-lower Campanian sediments and they are often abundant in the planktic foraminiferal assemblages of the lower Turonian. Tests affected by dissolution are mostly recorded in the upper Turonian-lower Santonian interval. The high planktic/benthic foraminiferal ratios (84.8-99.8\%) apparently indicate bathyal sedimentation.

The coeval distal shelf carbonate sediments at Site 95 also yielded occurrences of both Fingeria species (Fig. 3). Preservation is good to very good but a significant proportion of the specimens are fragmentary tests or exhibit traces of dissolution. The globular-chambered species, including those of Fingeria, are rather sporadic in occurrence, probably due to the unstable conditions in the uppermost layer of the oceanic water column. In contrast, the deeper-water species of heterohelicids and globotruncanids occur continuously and have stratigraphical ranges that can be correlated easily to those in the adjacent regions (e.g. Gulf of Mexico, southern USA).

\section{EVOLUTIONARY CLASSIFICATION}

The higher classification units are after Loeblich \& Tappan (1987). The composite palaeontological species concept (Georgescu \& Huber, 2007, 2009) is followed throughout.
Order Foraminiferida Eichwald, 1830

Suborder Globigerinina Delage \& Hérouard, 1896

Superfamily Rotaliporacea Sigal, 1958

Family Hedbergellidae Loeblich \& Tappan, 1961

Subfamily Hedbergellinae Loeblich \& Tappan, 1961 Genus Fingeria gen. nov.

Type species. Fingeria kingi (Trujillo, 1960).

Derivation of name. Genus named after Dr Kenneth Finger (University of California, Berkeley) for his contributions to the study of foraminifera; suffix '-ia' is added to his name.

Diagnosis. Late Cenomanian-early Campanian globularchambered trochospiral planktic foraminifera with incipient meridional ornamentation.

Species included. Fingeria loetterlei (Nauss, 1947) and F. kingi (Trujillo, 1960).

Description. Test is low to medium high trochospiral, consisting of globular chambers that increase in size at low to moderate, rarely high rates. Sutures are distinct and depressed, perpendicular to oblique on the previous whorl on the spiral side and straight and radial on the umbilical one. Periphery is broadly rounded, without peripheral structures. Umbilicus is small to medium sized, its diameter representing one-fifth to one-third of the maximum test diameter; the widest umbilici occur in evolved species. Aperture is a low to medium high arch, umbilicalextraumbilical in position and bordered by flaps. Ornamentation consists of scattered, often randomly distributed and occasionally aligned pustules and rugosities in the primitive species and aligned or not pustules, rugosities and occasional costellae in the evolved species; an ornamentation pattern that is loosely meridional or parallel to the periphery can be developed over isolated chambers. Test wall is calcitic, hyaline and perforate; pore diameter ranges from 1.7 to $4.9 \mu \mathrm{m}$.

Stratigraphical range. Turonian-lower Campanian (from the Helvetoglobotruncana helvetica Biozone to the Globotruncanita elevata Biozone).

\section{Geographical distribution. Cosmopolitan.}

Remarks. Fingeria is a directional lineage consisting of two composite palaeontological species, which present significant ornamentation variability; pustules are the dominant ornamentation elements but rugosities and faint costellae may occur over some chambers in some specimens. An incipient meridional pattern can sporadically occur in both species. These features separate it from Whiteinella, which has tests ornamented with scattered and isolated pustules. Fingeria differs from the Archaeoglobigerina blowi Pessagno, 1967-A. cretacea (d'Orbigny, 1840) group of species by having a broadly rounded and simple periphery rather than with an imperforate peripheral band bordered by two rows of pustules or weak keels and ornamentation with occasionally developed rugosities and incipient meridional pattern. It differs from Paracostellagerina Georgescu 


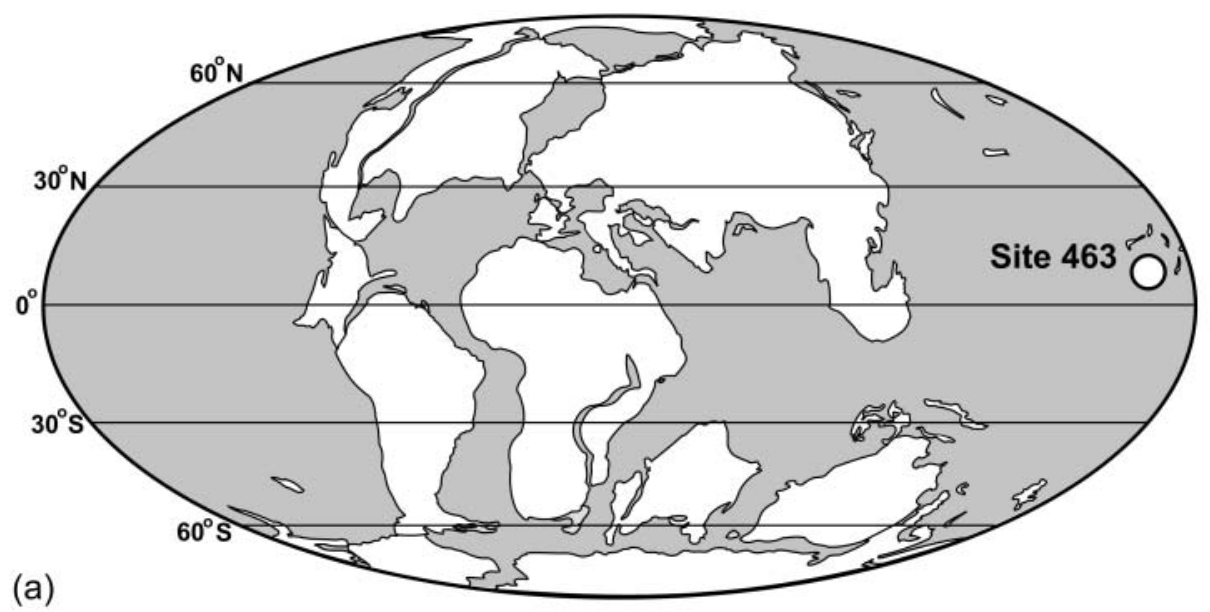

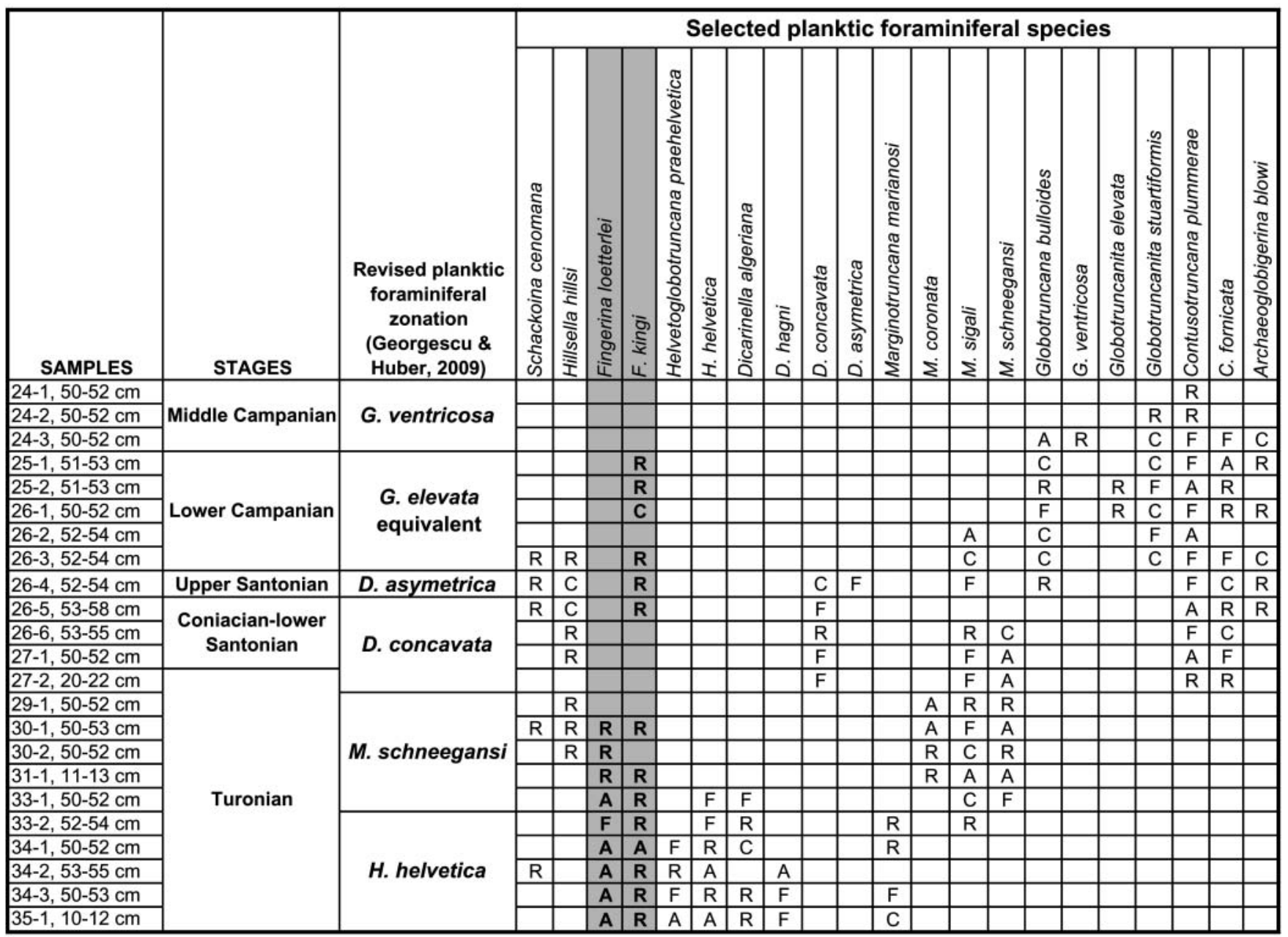

(b)

Fig. 2. (a) Geographical position and (b) stratigraphical distribution and frequencies of selected planktic foraminiferal species in the Turonianmiddle Campanian sediments at DSDP Site 463 (Mid-Pacific Mountains, equatorial Central Pacific). Frequency letter scale: R, rare (1-5 specimens/sample); C, common (6-10 specimens/sample); F, frequent (11-25 specimens/sample); and A, abundant ( $\geq 26$ specimens). The two Fingeria species are shaded in grey. Base map is after Hay et al. (1999). 


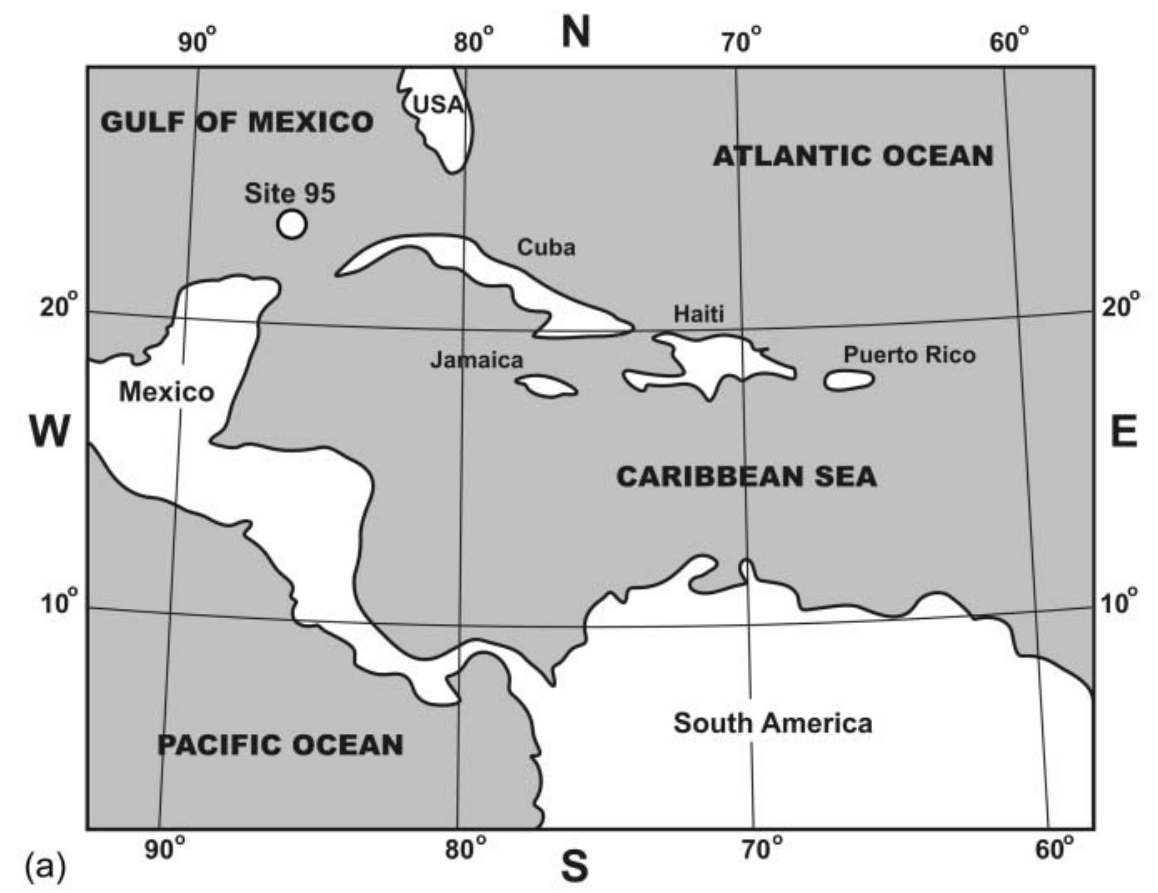

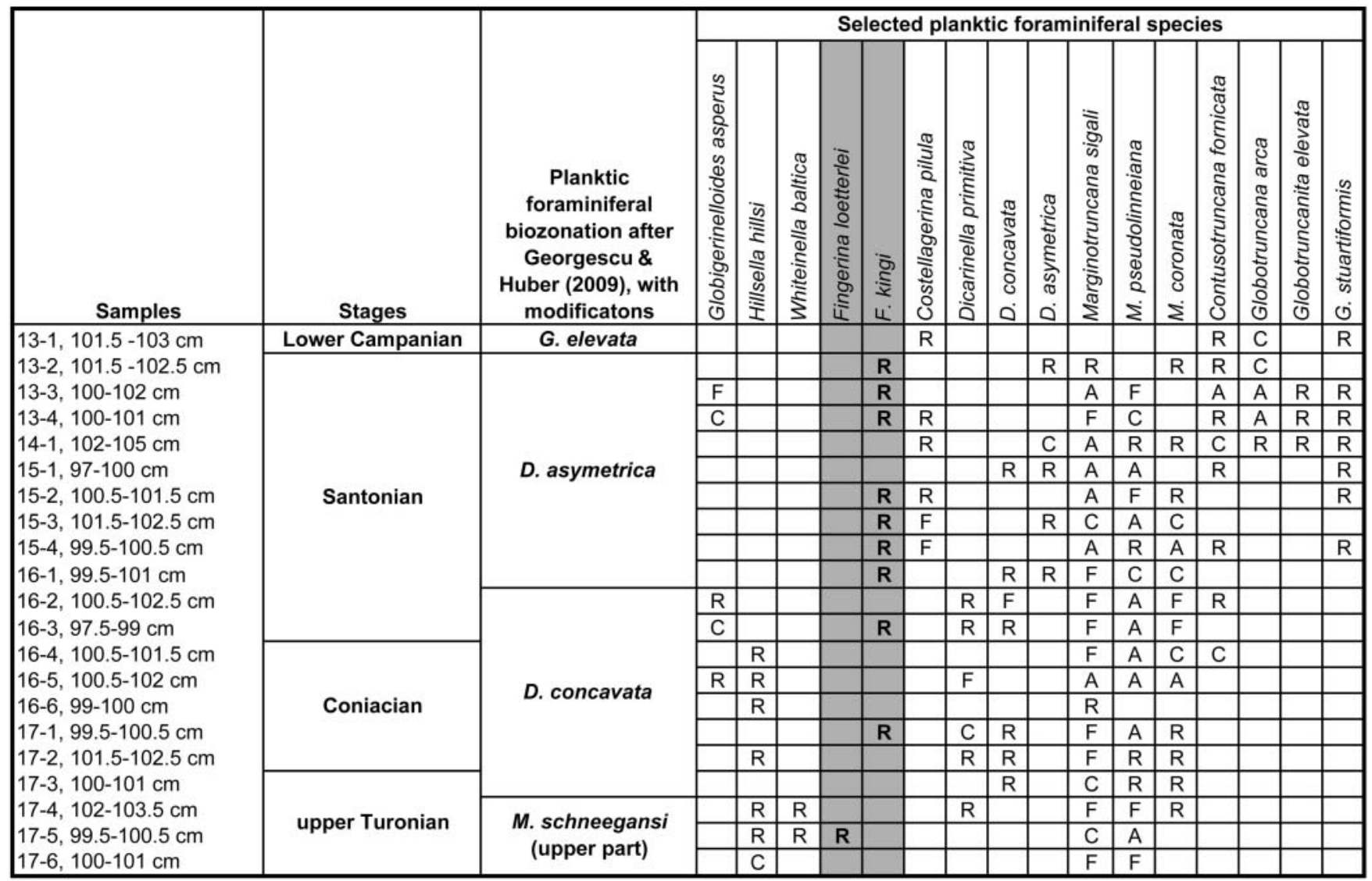

(b)

Fig. 3. (a) Geographical position and (b) stratigraphical distribution and frequencies of selected planktic foraminiferal species in the upper Turonian-lower Campanian sediments at DSDP Site 95 (Yucatan outer shelf, Caribbean region). See Figure 2 for frequency letter scale. 
\& Huber, 2006 (late Albian-early Cenomanian), Costellagerina Petters, El-Nakhal \& Cifelli, 1983 (Santonian-early Campanian) and Rugoglobigerina Brönnimann, 1952 (late CampanianMaastrichtian) mainly by lacking a consistently ornamented chamber surface with costellae that show well-developed meridional pattern or one that is parallel to the periphery. Meridionalla El-Nakhal, 1982 (type species: Hedbergella murphyi Marianos \& Zingula, 1966) is a trans-lineage genus based on nonexistent features (i.e. costellae) in the type species and can be considered valid only if the presence of consistent costellate ornamentation can be documented in the designated type species (El-Nakhal, 1982).

\section{Fingeria loetterlei (Nauss, 1947) - emended}

(Pl. 1, figs 1-6)

1937 Globigerina cretacea d'Orbigny; Loetterle: 44, pl. 7, fig. 1 (only).

1947 Globigerina loetterlei Nauss: 336, pl. 49, fig. 11.

1951 Globigerina loetterlei Nauss; Tappan: 4, pl. 1, fig. 19.

1953 Rotundina ordinaria Subbotina: 186, pl. 3, figs 7-9 (only).

1956 Globigerina cretacea d'Orbigny; Bolin: 292, pl. 39, figs 4-7,

13, 17 (only).

1962 Hedbergella loetterlei (Nauss); Tappan: 196, pl. 55, figs 3-5.

1965 Hedbergella loetterlei (Nauss); Takayanagi: 205, pl. 21, fig. 5.

1966 Hedbergella murphyi Marianos \& Zingula: 336, pl. 38, fig. 5.

1966 Hedbergella quadrata Marianos \& Zingula: 336, pl. 38, fig. 7.

1966 Hedbergella sp. 2; Douglas \& Sliter: 105, pl. 1, fig. 1.

1967 Hedbergella loetterlei (Nauss); Kent: 1448, pl. 183, figs 14-15.

1967 Hedbergella loetterlei (Nauss); Wall: 107, pl. 3, figs 13-21.

1969 Hedbergella murphyi Marianos \& Zingula; Douglas: 168, pl. 5, fig. 8 .

1969 Hedbergella bornholmensis Douglas \& Rankin: 193, fig. 6. 1974 Globigerina cretacea d'Orbigny; Cañon \& Ernst: 82, pl. 4, fig. 3.

1974 Globigerina wenzeli Cañon \& Ernst: 83, pl. 4, fig. 5.

1975 Hedbergella loetterlei (Nauss): North \& Caldwell: pl. 4, fig. 17.

1976 Whiteinella archaeocretacea Pessagno; Lamolda: 18, pl. 1, figs 1-9.

1977 Globigerina loetterlei Nauss; Masters: 464.

1981 Hedbergella loetterlei (Nauss); McNeil \& Caldwell: 254, pl. 21, fig. 1.

1987 Whiteinella sp. A; Frerichs \& Deiss: figs 4:7, 6:3.

1987 Whiteinella loetterlei (Nauss); Frerichs \& Deiss: fig. 6:2.

2000 Hedbergella murphyi Marianos \& Zingula; Petrizzo \& Premoli Silva: pl. 1, figs 1-4.

Emended description. Test low to medium high trochospiral consisting of $12-14$ globular chambers arranged in $2 \frac{1}{2}-3$ whorls; there are $4-6$, commonly $5-5 \frac{1}{2}$ chambers in the final whorl; chambers increase in size at low to high rate. Sutures are distinct, depressed, straight to slightly curved and perpendicular to oblique to the previous whorl on the spiral side and straight and radial on the umbilical side. Test convex-concave, slightly asymmetrical in edge view; periphery is broadly rounded, without peripheral structures. Umbilicus is small to medium sized, its diameter representing approximately one-fifth to one-third of the maximum test diameter. Aperture is a low arch, umbilicalextraumbilical in position and bordered by a thin, rarely preserved imperforate flap. Chamber surface is ornamented with dense pustules (maximum dimension 8.3-15.4 $\mu \mathrm{m}$ ) and rarely rugosities; ornamentation elements can be occasionally aligned but without presenting well-developed meridional arrangement. Test wall is calcitic, hyaline and perforate (pore diameter 2.3$4.1 \mu \mathrm{m})$.

Stratigraphical range. Turonian (from the $H$. helvetica Biozone to the lower part of Marginotruncana schneegansi Biozone).

Geographical distribution. Canada (Alberta, Manitoba, Saskatchewan), USA (Alaska, California, Colorado, Kansas, Minnesota, Nebraska, South Dakota), South America (Chile), Europe (Denmark, France, Spain), Russia, western North Atlantic Ocean (Blake Plateau) and equatorial Central Pacific Ocean (Mid-Pacific Mountains).

Remarks. The holotype of $F$. loetterlei is poorly preserved and is covered with thick glue on certain portions, mainly at the periphery; the ornamentation is almost completely removed by erosion and/or dissolution (P1. 1, Fig. 1). Fingeria loetterlei differs from Whiteinella baltica, $W$. brittonensis and $W$. paradubia by having ornamentation with occasionally aligned elements, which can be pustules and rarely rugosities. It differs from Costellagerina pilula (Belford, 1960) mainly by lacking costellae and a meridional ornamentation pattern and having the test wall with larger pores $(2.3-4.1 \mu \mathrm{m}$ rather than $1.0-1.9$ $\mu \mathrm{m})$. Rotundina ordinaria was described by Subbotina (1953) from the Turonian and Maastrichtian sediments of the middle Volga and Emba regions, respectively. The holotype of this species was selected from the Maastrichtian material and belongs to Rugoglobigerina hexacamerata Brönnimann, 1952; three of the four Turonian specimens are assigned herein to $F$. loetterlei. The ornamentation of $F$. loetterlei has been reinterpreted by El-Nakhal (1982, p. 34), who described it as consisting of '... meridionally arranged rugosities similar to those of Rugoglobigerina' based on the type illustrations; it appears obvious that this author confused the costellae for rugosities and subsequent articles by the same author (El-Nakhal, 1999, 2002) confirm this, ornamentation being described as 'costellate'. The holotype of $F$. murphyi was re-examined by Petrizzo \& Premoli Silva (2000, p. 306), who showed that it lacks costellate ornamentation and aligned pustules. They suggested that the species has closer affinities to Whiteinella rather than Hedbergella based on the wide umbilical area and pustulose surface. However, the poor state of preservation of the holotype (Pl. 1, fig. 2) represents an insurmountable impediment in drawing final conclusions on the validity of this species based only on the study of the holotype. Tests with high chamber size growth rate that were included within H. bornholmensis Douglas \& Rankin, 1969 occur sporadically in the $F$. loetterlei assemblages; they are assigned to the latter species due to the similar ornamentation 


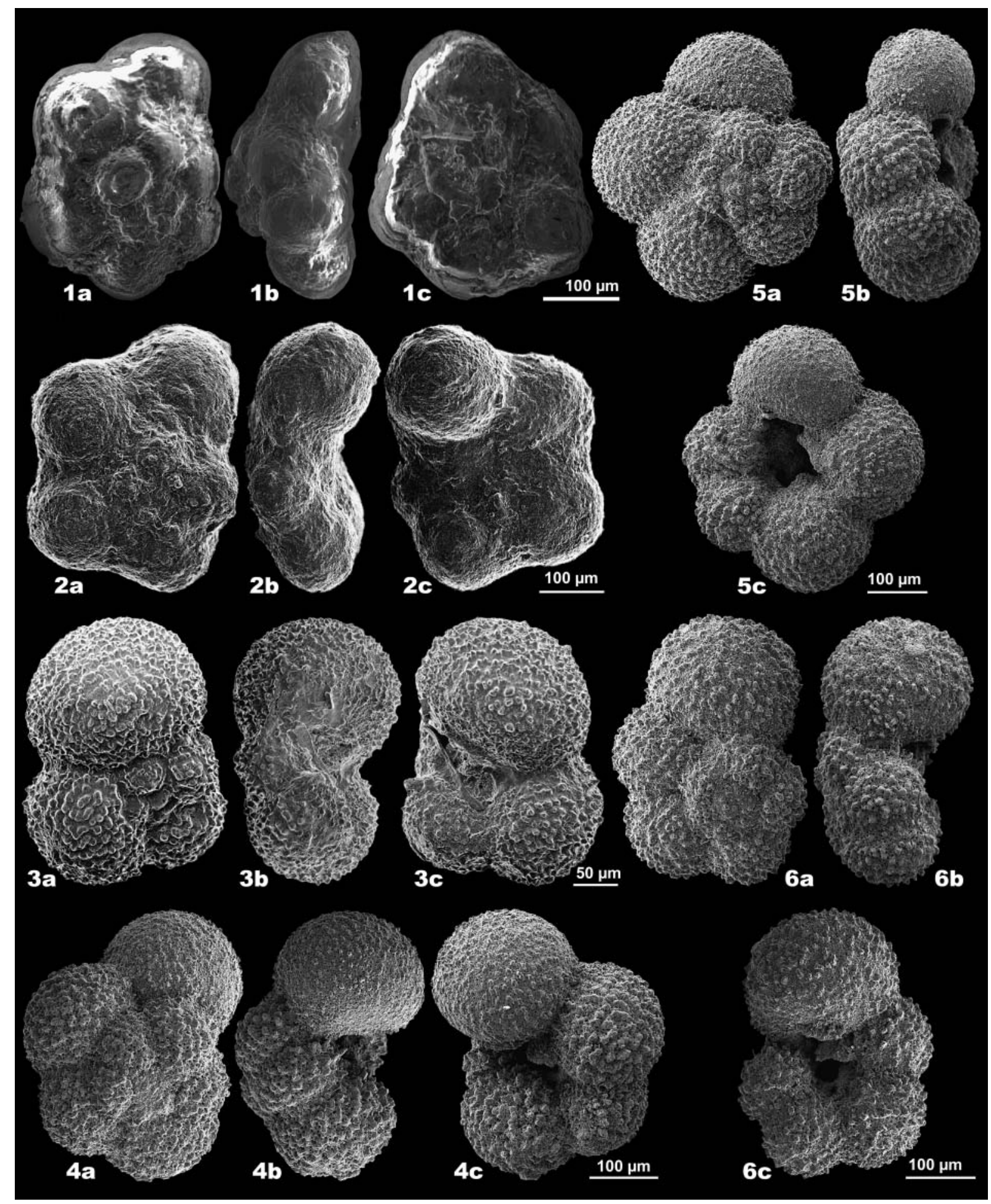

Explanation of Plate 1.

fig. 1. Holotype of Fingeria loetterlei (Nauss, 1947) originally figured as Globigerina loetterlei (Nauss, 1947, pl. 49, fig. 11) from the Lloydminster shale of the Clonmel Well No. 1 (Vermilion Area, Alberta, Canada). fig. 2. Holotype of Hedbergella murphyi (Marianos \& Zingula, 1966, pl. 38, fig. 5) from the Turonian of the Dry Creek, Tehama County, California (USA). fig. 3. Holotype of H. bornholmensis (Douglas \& Rankin, 1969 , fig. 6 A-C) from the Bavnodde Greensand (Denmark). fig. 4. Hypotype of $F$. loetterlei from the lower Turonian sediments ( $H$. helvetica Biozone) of the equatorial Central Pacific, Shatsky Rise, DSDP Site 463, Sample 35-1, 17-19 cm. fig. 5. Hypotype of F. loetterlei (Marianos \& Zingula, 1966) from the lower Turonian sediments (H. helvetica Biozone) of the equatorial Central Pacific, Shatsky Rise, DSDP Site 463, Sample 35-1, 17-19 cm. fig. 6. Hypotype of $F$. loetterlei from the lower Turonian sediments (H. helvetica Biozone) of the equatorial Central Pacific, Shatsky Rise, DSDP Site 463, Sample 35-1, 17-19 cm. 


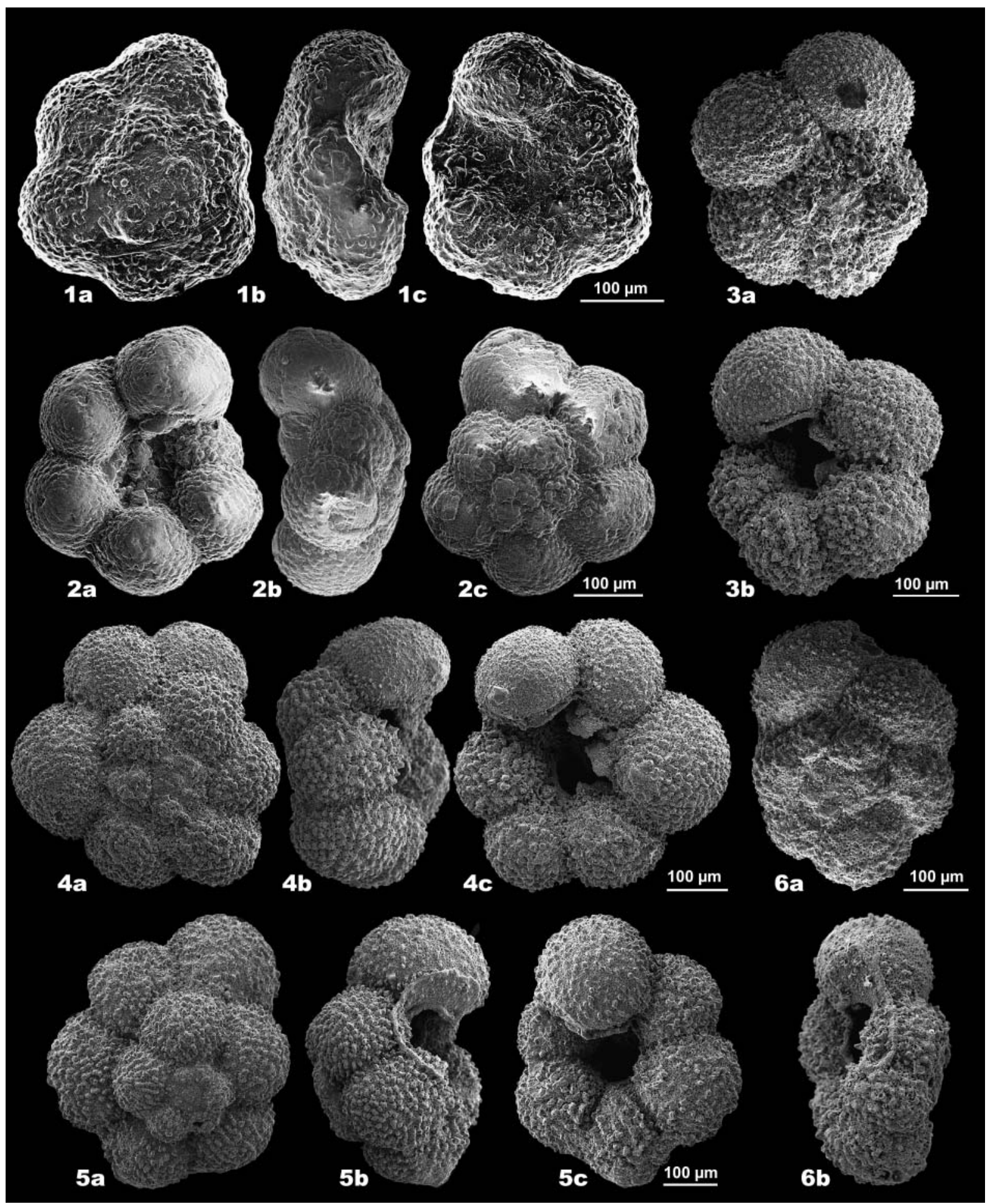

Explanation of Plate 2.

fig. 1. Holotype of Fingeria kingi (Trujillo, 1966) originally figured as Rugoglobigerina kingi (Trujillo, 1966, pl. 49, fig. 5) from the Coniacian sediments of Clover Creek, east of Reading, Shasta County, California (USA). fig. 2. Holotype of Archaeoglobigerina bosquensis (Pessagno, 1967, pl. 60, figs 10-12 fig. 3) from the Santonian sediments of Lover's Leap, McLennan County, Texas (USA). fig. 3. Hypotype of $F$. kingi from the lower Turonian sediments (M. schneegansi Biozone) of the equatorial Central Pacific, Shatsky Rise, DSDP Site 463, Sample 33-1, 50-52 cm. fig. 4. hypotype of F. kingi from the lower Turonian sediments (H. helvetica Biozone) of the equatorial Central Pacific, Shatsky Rise, DSDP Site 463, Sample 35-1, 17-19 cm. fig. 5. Hypotype of F. kingi from the lower Turonian sediments $(H$. helvetica Biozone) of the equatorial Central Pacific, Shatsky Rise, DSDP Site 463, Sample 35-1, 17-19 cm. fig. 6. Hypotype of F. kingi from the lower Turonian sediments (H. helvetica Biozone) of the equatorial Central Pacific, Shatsky Rise, DSDP Site 463, Sample 34-2, 53-55 cm. 


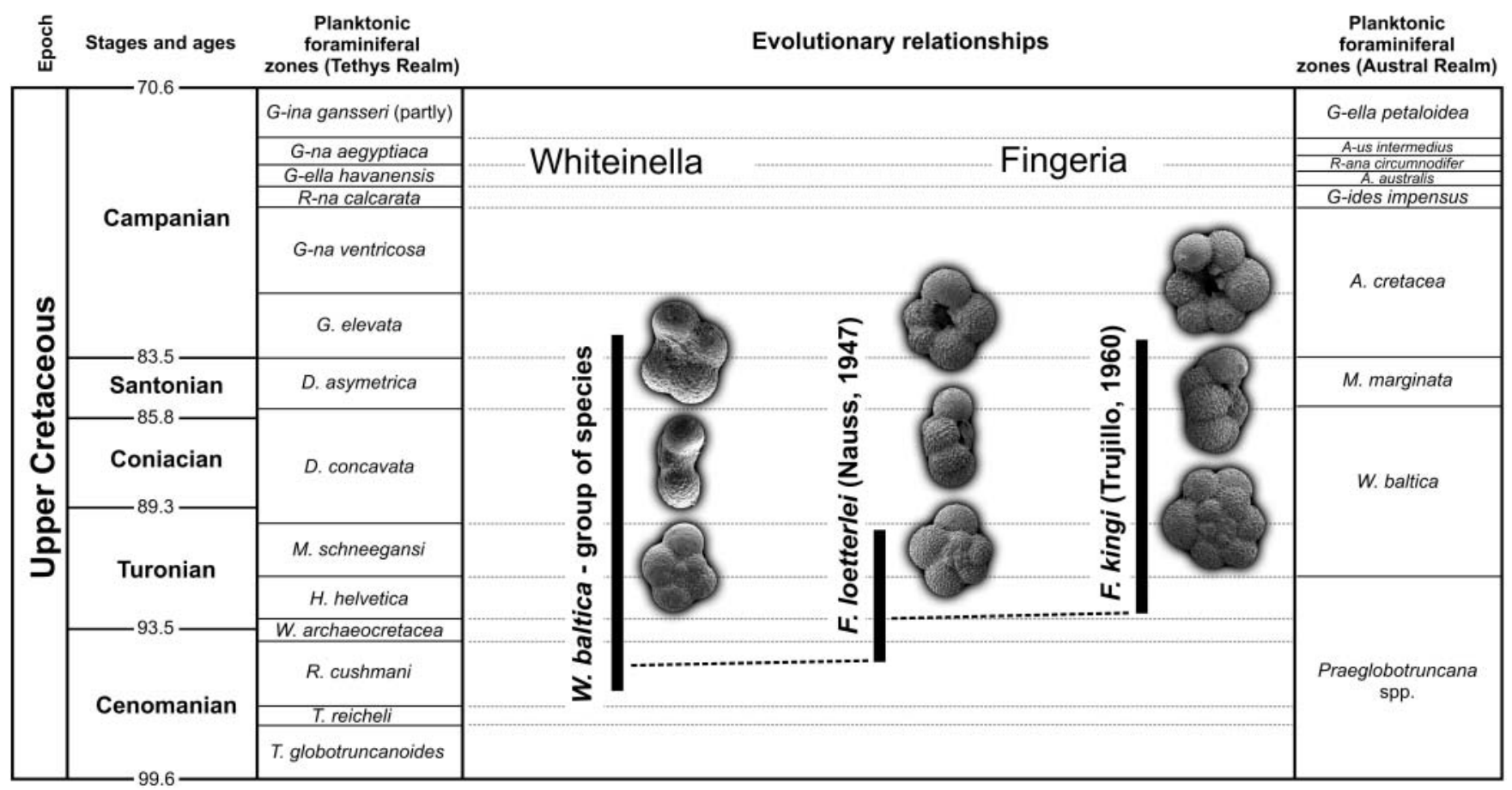

Fig. 4. Diagram presenting the evolutionary relationships between the species of Fingeria. Abbreviations: A., Archaeoglobigerina; A-us, Abathomphalus; D., Dicarinella; G., Globotruncanita; G-na, Globotruncana; G-ella, Globotruncanella; G-ina, Gansserina; G-ides, Globigerinelloides; H., Helvetoglobotruncana; M., Marginotruncana; R., Rotalipora; R-na, Radotruncana; R-ana, Rugotruncana; T., Thalmanninella; W., Whiteinella.

features and stratigraphical ranges. It is noteworthy that a similar taxonomic solution was taken by Huber (1994) when he considered Rugoglobigerina macrocephala Brönnimann, 1952 - a species with high chamber size growth rate in the last whorl and sporadic occurrences - the junior synonym of $R$. rugosa (Plummer, 1927), which is a frequent species with moderate chamber size growth increase rate.

Fingeria kingi (Trujillo, 1960)

(P1. 2, figs 1-6)

1937 Globigerina cretacea d'Orbigny; Loetterle: 44, pl. 7, fig. 2 (only).

1953 Rotundina ordinaria Subbotina: 186, pl. 3, fig. 6 (only).

1956 Globigerina cretacea d'Orbigny; Bolin: 292, pl. 39, fig. 8 (only).

1960 Rugoglobigerina kingi Trujillo: 339, pl. 49, fig. 5.

1960 Rugoglobigerina (Rugoglobigerina) plana Belford: 95, pl. 27, figs $1-5$, text-fig. 8 .

1965 Rugoglobigerina kingi Trujillo; Takayanagi: 228, pl. 29, fig. 4.

1966 Rugoglobigerina kingi Trujillo; Marianos \& Zingula: 339, pl. 38, fig. 6 .

1967 Rugoglobigerina sp.; Burckle et al.: fig. 2:4.

1967 Archaeoglobigerina bosquensis Pessagno: 316, pl. 60, figs 7-12.

1968 Rugoglobigerina kingi Trujillo; Scheibnerová: 80, pl. 19, fig. 5 .

1969 Hedbergella kingi (Trujillo); Douglas: 166, pl. 4, figs 6-7. 1969 Archaeoglobigerina bosquensis Pessagno; Douglas \& Rankin: 199, figs 10-11.
1971 Hedbergella kingi (Trujillo); Belford \& Scheibnerová: 334, pl. 4, figs 10-15.

1972 Archaeoglobigerina bosquensis Pessagno; Hanzlíková: 100, pl. 25, figs 11-13.

1973 Archaeoglobigerina bosquensis Pessagno; Frerichs \& Adams: 192, pl. 2, figs 8-9.

1976 Whiteinella kingi (Trujillo); Lamolda: 19, pl. 1, figs 10-23. 1977 Archaeoglobigerina? bosquensis Pessagno; Petters: pl. 3, figs 14-15.

1977 Archaeoglobigerina bosquensis Pessagno; Sliter: 542: pl. 9, figs 3-5.

1981 Archaeoglobigerina bosquensis Pessagno; Frerichs \& Dring: 68, pl. 3, figs 16-18.

1983 Archaeoglobigerina bosquensis Pessagno; Krasheninnikov \& Basov: 805, pl. 8, figs 1-8.

1983 Hedbergella plana Belford; Belford: pl. 3, figs 6-11.

1985 Archaeoglobigerina bosquensis Pessagno; Caron: 43, fig. 16:5-6.

1987 Archaeoglobigerina bosquensis Pessagno; Frerichs \& Deiss: fig. 10.2 .

1992 Archaeoglobigerina bosquensis Pessagno; Olsson \& Usmani: 313, fig. 7:1.

1994 Archaeoglobigerina bosquensis Pessagno; Huber: 41, pl. 7, figs $1-11$.

2000 Archaeoglobigerina bosquensis Pessagno; Petrizzo: fig. 14:1. 2001 Archaeoglobigerina bosquensis Pessagno; Petrizzo: fig. 8:8.

2006 Archaeoglobigerina bosquensis Pessagno; Georgescu: fig. 8: 11-13.

Emended description. Test low to medium high trochospiral consisting of 15-19 globular chambers arranged in $2 \frac{1}{2}-3$ whorls; 


\begin{tabular}{|c|c|}
\hline \multicolumn{2}{|c|}{ Genus: Fingeria - new } \\
\hline F. loetterlei (Nauss, 1947) & F. kingi (Trujillo, 1960) \\
\hline \multicolumn{2}{|l|}{ Total number of chambers } \\
\hline $12-14$ & $15-19$ \\
\hline \multicolumn{2}{|c|}{ Number of chambers in the last whorl } \\
\hline $4-6$ & $51 / 2-6$ \\
\hline \multicolumn{2}{|l|}{ Umbilicus diameter } \\
\hline $1 / 8-1 / 2 D_{\max }$ & $1 / 2-1 / 2 D_{\max }$ \\
\hline \multicolumn{2}{|l|}{ Periapertural structures } \\
\hline Flaps & Flaps \\
\hline \multicolumn{2}{|l|}{ Ornamentation elements } \\
\hline Pustules, rarely rugosities & Pustules, rarely rugosities and costellae \\
\hline \multicolumn{2}{|l|}{ Pustule maximum dimension $(\mu \mathrm{m})$} \\
\hline $8.3-15.4$ & $10.9-16.7$ \\
\hline \multicolumn{2}{|l|}{ Pore diameter $(\mu \mathrm{m})$} \\
\hline $2.3-4.1$ & $1.7-4.9$ \\
\hline
\end{tabular}

Fig. 5. Diagram showing the resemblances and differences of selected key features between the two species of the Fingeria lineage.

there are 5 $\frac{1}{2}-6$ chambers in the final whorl; chambers increase in size at a low to moderate rate. Sutures are distinct and depressed, straight or slightly curved and perpendicular to oblique to the previous whorl on the spiral side and straight and radial on the umbilical one. Test is asymmetrical, convexconcave in edge view; periphery is broadly rounded, without peripheral structures. Umbilicus is deep with diameter representing one-quarter to one-third of the test maximum diameter. Aperture is a low to medium high arch, situated in umbilicalextraumbilical position; it is bordered by a thin imperforate flap, which is rarely preserved. Chamber surface is ornamented with pustules (maximum dimension 10.9-16.7 $\mu \mathrm{m}$ ) and rarely rugosities and faint costellae, which can exhibit an arrangement that is incipiently meridional or parallel to the periphery, especially over the earlier chambers on the dorsal side. Test wall is calcitic, hyaline and perforate (pore diamete 1.7-4.9 $\mu \mathrm{m}$ ).
Stratigraphical range. Turonian-lower Campanian (from the lower part of $H$. helvetica Biozone to the lower part of G. elevata Biozone).

Geographical distribution. USA (Alaska, California, Colorado, Kansas, Minnesota, Nebraska, New Jersey, South Dakota, Texas, Wyoming), Mexico, Australia, Europe (Denmark, Slovakia, Spain), Russia, Africa (Morocco), Caribbean region (Yucatan outer shelf), South Atlantic Ocean (Falkland Plateau), Indian Ocean (Exmouth Plateau, Kerguelen Plateau, Naturaliste Plateau) and equatorial Central Pacific Ocean (Mid-Pacific Mountains).

Remarks. Two species were published simultaneously for this taxon, namely Rugoglobigerina kingi Trujillo, 1960 and Rugoglobigerina (Rugoglobigerina) plana (Belford, 1960). The former 
was published in the Journal of Paleontology, 34(2), for which the publication date is March 1960; in the absence of a specified day, the publication date should be considered to be 31 March 1960 (International Code of Zoological Nomenclature (ICZN), Article 21.3.1). Publication date for the latter, as mentioned in the Bureau of Mineral Resources, Geology and Geophysics Bulletin, 57, is 31 March 1960. As First Reviser (ICZN, Article 24.2.1), the present author's decision is to validate Rugoglobigerina kingi Trujillo, 1960 as Fingeria kingi (Trujillo, 1960) because it was published in a journal with wider distribution and the type material is more accessible. Fingeria kingi differs from $F$. loetterlei by having more chambers in the final whorl $\left(5^{1 / 2}-6\right.$ rather than 4 to 6), slower chamber increase in size and larger tests. It differs from $W$. baltica, $W$. brittonensis and $W$. paradubia mainly in the development of ornamentation that is incipiently meridional or parallel to the periphery, consisting of pustules and rarely rugosities and faint costellae. Large-sized specimens $\left(D_{\max }=0.459-0.471 \mathrm{~mm}\right)$ of $F$. kingi are frequent throughout the stratigraphical range of the species.

\section{CONCLUSIONS}

Taxonomic re-evaluation of some coarsely ornamented planktic foraminifera of Late Cretaceous (late Cenomanian-early Campanian) age reveals the existence of a new genus, Fingeria, which includes F. loetterlei (Nauss, 1947) and F. kingi (Trujillo, 1960) (Fig. 4). The two species are characterized by coarse ornamentation consisting of pustules, which can fuse occasionally to form rugosities and, more rarely, costellae. Most of the specimens of $F$. loetterlei and $F$. kingi have randomly orientated ornamentation elements; an incipient meridional pattern is occasionally developed. From a purely morphological point of view, the ornamentation characteristics of Fingeria appear intermediate between those of Whiteinella (randomly oriented scattered pustules) and Costellagerina and Rugoglobigerina (well-developed costellae with an ornamentation pattern that is meridional or parallel to the periphery).

There are discrete evolutionary changes in the Fingeria lineage: increase in the total number of chambers, number of chambers of the last whorl, umbilical diameter, pustule maximum dimension and pore size (Fig. 5). This demonstrates that at least in some lineages of globular-chambered species the Cretaceous evolution process happened mostly at the test ultrastructure level (Georgescu, 2010a). The general resemblances in the chamber shape, test ornamentation and periapertural structures (i.e. flaps) between $F$. loetterlei and $W$. baltica indicate that the ancestor of the Fingeria lineage is among the whiteinellid group, which first occurred in the upper Cenomanian. The transition between the two taxa happened with the ornamentation coarsening, generated by formation of rugosities and development of a loose meridional ornamentation pattern.

There is no compelling evidence to support the existence of any descendant from this lineage. Costellagerina of the Santonian-early Campanian is ornamented with well-developed meridionally arranged costellae. However, its pores are much smaller than those of the contemporaneous $F$. kingi $(1.0-1.9 \mu \mathrm{m}$ rather than 1.7-4.9 $\mu \mathrm{m})$. Therefore, it appears more reasonable to consider a whiteinellid ancestry for Costellagerina, as suggested by Huber (1994) based on detailed test wall morphology and growth patterns. Archaeoglobigerina australis Huber, 1990 was considered by Huber (1994) to be the descendant of $A$. bosquensis, the latter being considered herein a junior synonym of $F$. kingi. Although specimens of $A$. australis with an incipient meridional ornamentation pattern were observed during this study in the late Campanian-Maastrichtian age material from ODP Hole 689B, the pore size of the two species shows significant differences. Pore diameter is larger in F. kingi (1.7$4.9 \mu \mathrm{m})$ and smaller in its presumed descendant, A. australis $(1.5-3.1 \mu \mathrm{m})$. Additional data are necessary to clarify the phylogenetic relationships between the two species in the absence of a mechanism to explain such a decrease in pore diameter and similar examples in the Cretaceous planktic foraminiferal evolution.

\section{ACKNOWLEGEMENTS}

The author thanks Malcolm B. Hart (University of Plymouth) for the thoughtful comments and criticism that significantly improved the quality of the manuscript. The author is grateful to B.T. Huber (NMNH, Washington, D.C., USA) for help and guidance during his 2005-2006 stay at the Smithsonian Institution and the ESEM images of the holotype of Rugoglobigerina kingi Trujillo, 1960. Help from K.L. Finger (University of California, Berkeley), who made available the holotype of Globigerina loetterlei Nauss, 1947, is kindly acknowledged. The author is indebted to L.V. Hills (University of Calgary, Canada), whose pre-submittal review significantly increased manuscript quality. M. Schoel (Microscope and Imaging Facility, University of Calgary, Canada) and S. Whittaker (NMNH) are thanked for professional and enthusiastic help during the SEM/ESEM operations. The DSDP/ODP/IODP headquarters are thanked for allowing the resampling of the relevant portions of DSDP Sites 95 and 463.

\section{Manuscript received 8 March 2010 Manuscript accepted 6 September 2010 Scientific editing by Alan Lord}

\section{REFERENCES}

Belford, D.J. 1960. Upper Cretaceous Foraminifera from the Toolonga Calcilutite and Gingin Chalk, Western Australia. Bureau of Mineral Resources, Geology and Geophysics Bulletin, 57: 1-198.

Belford, D.J. 1983. Note on costellate planktonic foraminifera, and the generic designation of Late Cretaceous forms from Western Australia. Bureau of Mineral Resources, Geology and Geophysics Bulletin Paleontological Papers, 217: 1-9.

Belford, D.J. \& Scheibnerová, V. 1971. Turonian foraminifera from the Carnarvon Basin, Western Australia and their palaeogeographical significance. Micropaleontology, 17: 331-344.

Bolin, E.J. 1956. Upper Cretaceous Foraminifera, Ostracoda, and Radiolaria from Minnesota. Journal of Paleontology, 30: 278-298.

Brönnimann, P. 1952. Globotruncanidae from the Upper Cretaceous (Cenomanian-Maestrichtian) of Trinidad, F. W. I. Bulletins of American Paleontology, 140: 1-71.

Brönnimann, P. \& Brown, N.K. Jr 1958. Hedbergella, a new name for a Cretaceous planktonic foraminiferal genus. Journal of Washington Academy of Sciences, 48: 15-17.

Burckle, L.H., Saito, T. \& Ewing, M. 1967. A Cretaceous (Turonian) core from the Naturaliste Plateau southeast Indian Ocean. Deep-Sea Research, 14: 421-426.

Cañon, A. \& Ernst, M. 1974. Magallanes Basin Foraminifera. In: Natland, M.L., Eduardo Gonzalez, P., Cañon, A. \& Ernst, M. (Eds), A System of Stages for Correlation of Magallanes Basin Sediments. The Geological Society of America Memoirs, 139: 61-117. 
Caron, M. 1983. Taxonomie et phylogenie de la famille des Globotruncanidae. Zitteliana, 10: 677-681.

Caron, M. 1985. Cretaceous planktic foraminifera. In: Bolli, H.F., Saunders, J.F. \& Perch-Nielsen, K. (Eds), Plankton Stratigraphy. Cambridge University Press, Cambridge, 17-86.

Delage, Y. \& Hérouard, E. 1896. Traité de zoologie concrete. Tome I: La cellule et les protozoaires. Schleicher Frères, Paris, 584pp.

Douglas, R.G. 1969. Upper Cretaceous planktonic foraminifera in northern California Part 1 - Systematics. Micropaleontology, 15: 151-209.

Douglas, R.G. \& Rankin, C. 1969. Cretaceous planktonic foraminifera from Bornholm and their zoogeographic significance. Lethaia, 2: 185-217.

Douglas, R.G. \& Sliter, W.V. 1966. Regional distribution of some Cretaceous Rotaliporidae and Globotruncanidae (Foraminiferida) within North America. Tulane Studies in Geology, 4: 89-131.

Eicher, D.L. 1973. Phylogeny of the late Cenomanian planktonic foraminifer Anaticinella multiloculata (Morrow). Journal of Foraminiferal Research, 2: 184-190.

Eichwald, C.E.von. 1830. Zoologia specialis II. D. E. Eichwaldus, Vilnae, 323pp.

El-Nakhal, H. 1982. Meridionalla, a new foraminiferal genus (Globigerinacea, Late Cretaceous). Research Journal of Aleppo University, 4 $33-35$.

El-Nakhal, H. 1999. The relation between the Late Cretaceous foraminiferal genera Meridionalla El-Nakhal (1982) and Costellagerina Petters and others (1983). Journal of Foraminiferal Research, 29: 85.

El-Nakhal, H. 2002. Classification of the meridionally costellate Cretaceous planktonic foraminifera. Journal of Micropaleontology, 21: 1-8.

Frerichs, W.E. \& Adams, P.R. 1973. Correlation of the Hilliard Formation with the Niobrara Formation. Wyoming Geological Association, Guidebook, 25th Field Conference, 187-192.

Frerichs, W.E. \& Deiss, A.P. 1987. Planktic foraminifera from the type area of the Fort Hays Limestone. Contributions to Geology, University of Wyoming, 25: 11-22.

Frerichs, W.E. \& Dring, N.F. 1981. Planktonic foraminifera from the Smoky Hill Shale of West Central Texas. Journal of Foraminiferal Research, 11: 47-69.

Georgescu, M.D. 2006. Santonian-Campanian planktonic foraminifera in the New Jersey coastal plain and their distribution related to the relative sea-level changes. Canadian Journal of Earth Sciences, 43: $101-120$.

Georgescu, M.D. 2007. A new planktonic heterohelicid foraminiferal genus from the Upper Cretaceous (Turonian). Micropaleontology, 53: 212-220.

Georgescu, M.D. 2009a. On the origins of Superfamily Heterohelicacea Cushman, 1927 and polyphyletic nature of planktonic foraminifera. Revista Española de Micropaleontología, 41: 107-144.

Georgescu, M.D. 2009b. Taxonomic revision and evolutionary classification of the biserial Cretaceous planktic foraminiferal genus Laeviheterohelix Nederbragt, 1991. Revista Mexicana de Ciencias Geológicas, 26: 315-334.

Georgescu, M.D. 2009c. Upper Albian-lower Turonian nonschackoinid planktic foraminifera with elongate chambers: morphology reevaluation, taxonomy and evolutionary classification. Revista Española de Micropaleontología, 41: 255-293.

Georgescu, M.D. 2010a. Transition from the typological to evolutionary classification of the Cretaceous planktic foraminifera: case study of Anaticinella Eicher, 1973. Micropaleontology, 55: 589-616.

Georgescu, M.D. 2010b. Origin, taxonomic revision and evolutionary classification of the late Coniacian-early Campanian planktic foraminifera with multichamber growth in the adult stage. Revista Española de Micropaleontología, 42: 59-118.

Georgescu, M.D. \& Abramovich, S. 2008a. A new serial Cretaceous planktic foraminifer (Family Heterohelicidae Cushman, 1927) from the Upper Maastrichtian of the equatorial Central Pacific. Journal of Micropaleontology, 27: 117-123.

Georgescu, M.D. \& Abramovich, S. 2008b. Taxonomic revision and phylogenetic classification of the Late Cretaceous (Upper SantonianMaastrichtian) serial planktonic foraminifera (Family Heterohelicidae
Cushman, 1927) with peripheral test wall flexure. Revista Española de Micropaleontología, 40: 97-114.

Georgescu, M.D. \& Abramovich, S. 2009. Short nomenclature note: A new name for the Upper Cretaceous planktic foraminiferal genus Hendersonia Georgescu and Abramovich, 2008. Revista Española de Micropaleontología, 41: p. 215.

Georgescu, M.D. \& Huber, B.T. 2006. Paracostellagerina nov. gen., a meridionally costellate planktonic foraminiferal genus of the middle Cretaceous (latest Albian-earliest Cenomanian). Journal of Foraminiferal Research, 36: 368-373.

Georgescu, M.D. \& Huber, B.T. 2007. Taxonomic revision of the late Campanian-Maastrichtian (Late Cretaceous) planktic foraminiferal genus Rugotruncana Brönnimann and Brown, 1956, and a new paleontological species concept for planktic foraminifera. Journal of Foraminiferal Research, 37: 150-159.

Georgescu, M.D. \& Huber, B.T. 2008. Taxonomic re-evaluation and phylogeny of the stellate planktonic foraminiferal genus Hastigerinoides Brönnimann, 1952. Journal of Foraminiferal Research, 38: $52-58$.

Georgescu, M.D. \& Huber, B.T. 2009. Early evolution of the Cretaceous serial planktic foraminifera (late Albian-Cenomanian). Journal of Foraminiferal Research, 39: 335-360.

Georgescu, M.D., Saupe, E.E. \& Huber, B.T. 2009. Morphometric and stratophenetic basis for phylogeny and taxonomy in Late Cretaceous gublerinid planktonic foraminifera. Micropaleontology, 54: 397-424.

Gradstein, F.M., Ogg, J.G. \& Smith, A.G. 2004. A Geologic Time Scale 2004. Cambridge University Press, Cambridge, 589pp.

Hanzlíková, E. 1972. Carpathian Upper Cretaceous Foraminiferida of Moravia (Turonian-Maastrichtian). Rozpravy Ústřednĩho Ústavu Geologického, 39: 1-160.

Hart, M.B. 1999. The evolution and biodiversity of Cretaceous planktonic Foraminiferida. Geobios, 32: 247-255.

Hart, M.B., Oxford, M.J. \& Hudson, W. 2002. The early evolution and palaeobiogeography of Mesozoic planktonic foraminifera. In: Crame, J.A. \& Owen, A.W. (Eds), Palaeobiogeography and Biodiversity Change: the Ordovician and Mesozoic-Cenozoic Radiations. Geological Society, London, Special Publications, 194: 115-125.

Hay, W.H., DeConto, R.M., Wold, C.N., Wilson, K.M., Voigt, S., Schulz, M., Wold, A.R., Dullo, W.C., Ronov, A.B., Balukhovsky, A.N. \& Söding, E. 1999. Alternative global Cretaceous paleogeography. In: Barrera, E. \& Johnson, C.C. (Eds), Evolution of the Cretaceous Ocean-Climate System. Geological Society of America, Special Publication, 332: 1-47.

Hennig, W. 1950. Grundzüge einer Theorie der phylogenetischen Systematik. Deutscher Zentralverlag, Berlin, 370pp.

Hennig, W. 1966. Phylogenetic Systematics. University of Illinois Press, Urbana, 406pp.

Huber, B.T. 1990. Maestrichtian planktonic foraminifer biostratigraphy of the Maud Rise (Weddell Sea, Antarctica): ODP Leg 113 Holes 689B and 690C. In: Barker, P.F., Kennett, J.P. et al. (Eds), Proceedings of the Ocean Drilling Program, Scientific Results, 113: 489-513. Ocean Drilling Program, College Station, TX.

Huber, B.T. 1992. Upper Cretaceous planktic foraminiferal zonation for the Austral Realm. Marine Micropaleontology, 20: 107-128.

Huber, B.T. 1994. Ontogenetic Morphometrics of Some Late Cretaceous Trochospiral Planktonic Foraminifera from the Austral Realm. Smithsonian Contributions to Paleobiology, 77: 1-85.

Kent, H.C. 1967. Microfossils from the Niobrara Formation (Cretaceous) and equivalent strata in northern and western Colorado. Journal of Paleontology, 41: 1433-1456.

Krasheninnikov, V.A. \& Basov, I.A. 1983. Stratigraphy of Cretaceous sediments of the Falkland Plateau based on planktonic foraminifers, Deep Sea Drilling Project, Leg 71. In: Ludwig, W.J., Krasheninnikov, V.A. et al. (Eds), Initial Reports of the Deep Sea Drilling Project, 71: 789-820. United States Government Printing Office, Washington.

Lamolda, M.A. 1976. Analisis del crecimiento de Whiteinella archaeocretacea Pessagno, 1967 y de Whiteinella kingi (Trujillo, 1960). Revista Española de Micropaleontología, 8: 15-22.

Loeblich, A.R.Jr \& Tappan, H. 1961. Cretaceous planktonic foraminifera: Part I - Cenomanian. Micropaleontology, 7: 257-304. 
Loeblich, A.R.Jr \& Tappan, H. 1987. Foraminiferal genera and their classification. Van Nostrand Reinhold, New York, 970pp.

Loetterle, G. 1937. The Micropaleontology of the Niobrara Formation in Kansas, Nebraska, and South Dakota. Nebraska Geological Survey Bulletin, 12: 1-73.

Marianos, A.W. \& Zingula, R.P. 1966. Cretaceous planktonic foraminifers from Dry Creek, Tehama County, California. Journal of Paleontology, 40: 328-342.

Masters, F.A. 1977. Mesozoic Planktonic Foraminifera. In: Ramsay, A.T.S. (Ed.), Oceanic Micropaleontology, 1: 301-731. Academic Press, London.

McNeil, D.H. \& Caldwell, W.G.E. 1981. Cretaceous rocks and their foraminifera in the Manitoba Escarpment. The Geological Association of Canada Special Paper, 21: 1-439.

Mesozoic Planktonic Foraminifera Working Group. 2006. Mesozoic Planktic Foraminiferal Taxonomic Dictionary, Huber, B.T. (Ed.). Available at: www.chronos.org.

Nauss, A.W. 1947. Cretaceous microfossils of the Vermillon area, Alberta. Journal of Paleontology, 21: 329-434.

North, B.R. \& Caldwell, W.G.E. 1975. Illustrations of Canadian fossils. Cretaceous foraminifera from Saskatchewan and Manitoba. Geological Survey of Canada Paper, 74-38: 1-35.

Olsson, R.K. \& Usmani, P.A. 1992. Upper Cretaceous foraminifera in Santonian to Maestrichtian depositional sequences in the New Jersey Coastal Plain. In: Ishizaki, K. \& Saito, T. (Eds), Centenary of Japanese Micropaleontology, Terra Scientific Publishing Company, Tokyo, 301-315.

d'Orbigny, A. 1840. Mémoire sur les foraminifères de la craie blanche du basin du Paris. Mémoires de la Société Géologique de France, 4: 1-51.

Pessagno, E.A.Jr. 1967. Upper Cretaceous planktonic foraminifera from the western Gulf Coastal Plain. Palaeontographica Americana, 5(37): 243-445.

Petrizzo, M.R. 2000. Upper Turonian-lower Campanian planktonic foraminifera from southern mid-high latitudes (Exmouth Plateau, NW Australia): biostratigraphy and taxonomic notes. Cretaceous Research, 21: 479-505.

Petrizzo, M.R. 2001. Late Cretaceous planktonic foraminifera from Kerguelen Plateau (ODP Leg 183): new data to improve the Southern Ocean biozonation. Cretaceous Research, 22: 829-855.

Petrizzo, M.R. \& Premoli Silva, I. 2000. Upper Cretaceous meridionally costellate hedbergellids: the genus Meridionalla El-Nakhal, 1982 vs. the genus Costellagerina Petters, El-Nakhal and Cifelli, 1983. Journal of Foraminiferal Research, 30: 306-309.

Petters, S.W. 1977. Upper Cretaceous planktonic foraminifera from the subsurface of the Atlantic Coastal Plain of New Jersey. Journal of Foraminiferal Research, 7: 165-187.
Petters, S.W., El-Nakhal, H.A. \& Cifelli, R. 1983. Costellagerina, a new Late Cretaceous globigerine foraminiferal genus. Journal of Foraminiferal Research, 13: 247-251.

Plummer, H.J. 1927. Foraminifera of the Midway Formation in Texas. University of Texas Bulletin, 2644: 1-206.

Robaszynski, F., Caron, M.(coordinators). \& The, European Working Group on Planktonic Foraminifera. 1979. Atlas of Mid Cretaceous Planktonic Foraminifera - Part 1. Cahiers de Micropaléontologie, 1: $1-185$.

Robaszynski, F. \& Caron, M. 1995. Foraminifères planctoniques du Crétacé: commentaire de la zonation Europe-Mèditerranée. Bulletin de la Société Géologique de France, 6: 681-692.

Scheibnerová, V. 1968. Middle and Upper Cretaceous microbiostratigraphy of the Klippen Belt (West Carpathians). Acta Geologica et Geographica Universitatis Comenianae, 17: 5-98.

Sigal, J. 1952. Aperçu stratigraphique sur la micropaléontologie du Crétacé. Alger, 19th International Geological Congress, Monographies regionales, $1^{\text {re }}$ ser., Algérie, 26: 1-52.

Sigal, J. 1958. La classification actuelle des familles de foraminifères planctoniques du Crétacé. Compte Rendu des Séances, Société Géologique de France, 1958: 262-265.

Sliter, W.V. 1977. Cretaceous foraminifera from the Southwest Atlantic Ocean, Leg 36, Deep Sea Drilling Project. In: Baker, P.F., Dalziel, I.W.D. et al. (Eds), Initial Reports of the Deep Sea Drilling Project, 36: 519-573. United States Government Printing Office, Washington.

Steineck, P.L. \& Fleisher, R.L. 1978. Towards the classical evolutionary reclassification of Cenozoic Globigerinacea (Foraminiferida). Journal of Paleontology, 52: 618-635.

Subbotina, T.N. 1953. Iskopaemie Foraminifery SSSR (Globigerinidy, Khantkeninidy i Globorotaliidy). Trudy vsesoyuznogo neftyanogo nauchno-isledovatelskogo geologo-razvedochnovo instituta, 76: 1-296. [In Russian.]

Takayanagi, Y. 1965. Upper Cretaceous planktonic foraminifera from the Putah Creek subsurface section along the Yolo-Solano line, California. Science Reports of the Tohoku University, 36: 161-237.

Tappan, H. 1951. North Alaska index foraminifera. Contributions from the Cushman Foundation for Foraminiferal Research, 2: 1-9.

Tappan, H. 1962. Foraminifera from the Arctic Slope of Alaska, Part 3, Cretaceous foraminifera. United States Geological Survey Professional Paper, 236-C: 91-209.

Trujillo, E.F. 1960. Upper Cretaceous foraminifera from near Redding, Shasta County, California. Journal of Paleontology, 34: 290-346.

Wall, J.H. 1967. Cretaceous foraminifera of the Rocky Mountains Foothills, Alberta. Research Council of Alberta Bulletin, 20: 1-185. 
What is the Lyell Collection?

Launched in $\mathbf{2 0 0 7}$ to celebrate $\mathbf{2 0 0}$ years of the Geological Society of London, the Lyell Collection is an online collection comprising the Society's journal titles, Special Publications and key book series. Cutting edge science sits alongside important historical material, all captured and presented to the highest electronic standards and benefiting from the extensive functionality of HighWire Press' platform.

With 230000 peer-reviewed pages, 24000 articles and nearly 1000 volumes, the Lyell Collection is an invaluable tool for the researcher and student alike.

- Full text in HTML and PDF format

- Actively linking to cited references

- Free public access to alerts, search functions and abstracts

- Selected open access articles

- Hosted by Highwire Press

\section{Individual access to the Lyell Collection?}

Fellows of the Geological Society enjoy extensive access to Lyell Collection content, including:

- JGS, QJEGH, GEEA or PG (including the full archive - when subscribed to as your free or additional journal option)

- The historical Transactions of the Geological Society of London (1811-1856)

- The Books Archive (all Special Publications, Memoirs and Engineering Geology Special Publications published prior to the current and three previous calendar years)

- The option to access all current titles via the Full Book Collection

To find out more about becoming a Fellow visit www.geolsoc.org.uk/join

\section{Library access to the Lyell Collection?}

Access to the full content of the Lyell Collection is via a range of subscription options, or pay-per-view. See the table below for further details. Additional content added for the 2011 subscription year is included in Lyell Collection Complete subscriptions.
New Developments for 2011

Full functionality of $\mathrm{H} 2 \mathrm{O}$

All Lyell collection titles will have migrated to Highwire Press' enhanced hosting platform, benefits include:

- advanced research tools

- cross journal alerts

- instant indexing

- inter-journal linking

New titles

Two new journal titles launched on the Lyell Collection in 2010 will be included for all 2011 subscribers to Lyell Collection Complete (LCC):

- Journal of Micropaleontology

- Petroleum Geoscience

In addition, two new archival titles will be launched on the Lyell Collection in 2011 and made available to LCC subscribers at no additional charge:

- Transactions of the Edinburgh society

- Transactions of the Glasgow society

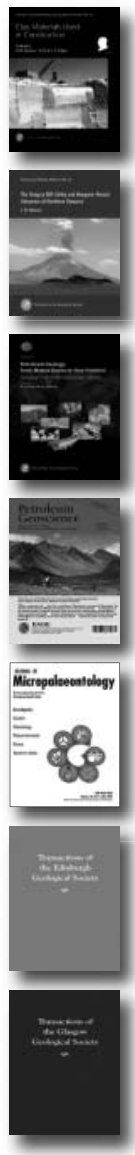

\section{Lyell Collection for libraries 2011: content and prices}

\begin{tabular}{|c|c|c|c|c|c|c|}
\hline TITLE & 2011 Products & 2011 Content & Access options & UK price $f^{*}$ & RoW price $\mathrm{f}^{*}$ & RoW price US\$* \\
\hline \multirow[t]{3}{*}{ Lyell Collection Complete } & \multirow[t]{3}{*}{ LCC } & SP, JGS, QJEGH, GEEA, PG, & LCC online-only & $f 3,487$ & $f 3,704$ & $\$ 7,408$ \\
\hline & & SJG, PYGS, JM, Transactions, & LCC online + print & $f 3,836$ & $f 4,074$ & $\$ 8,148$ \\
\hline & & Memoirs, EGSPs, PGC series & LCC online + SP print** & $f 3,687$ & $f 3,904$ & $\$ 7,808$ \\
\hline \multirow[t]{2}{*}{ Special Publications } & \multirow[t]{2}{*}{ SP } & \multirow[t]{2}{*}{$340+$ volumes } & SP online-only & $f 2,055$ & $f 2,142$ & $\$ 4,285$ \\
\hline & & & SP online + print & $f 2,260$ & $f 2,357$ & $\$ 4,713$ \\
\hline \multirow[t]{2}{*}{ Journal of the Geological Society } & \multirow[t]{2}{*}{ JGS } & \multirow[t]{2}{*}{1845 to current } & JGS online-only & f802 & f891 & $\$ 1,782$ \\
\hline & & & JGS online + print & f883 & f980 & $\$ 1,960$ \\
\hline \multirow{2}{*}{$\begin{array}{l}\text { Quarterly Journal of Engineering } \\
\text { Geology and Hydrogeology }\end{array}$} & \multirow[t]{2}{*}{ QJEGH } & \multirow[t]{2}{*}{1967 to current } & QJEGH online-only & f380 & f425 & $\$ 851$ \\
\hline & & & QJEGH online + print & f418 & f468 & $\$ 936$ \\
\hline \multirow{2}{*}{$\begin{array}{l}\text { Geochemistry: Exploration, } \\
\text { Environment, Analysis }\end{array}$} & \multirow[t]{2}{*}{ GEEA } & \multirow[t]{2}{*}{2001 to current } & GEEA online-only & f205 & f232 & $\$ 464$ \\
\hline & & & GEEA online + print & f225 & f255 & $\$ 510$ \\
\hline \multirow[t]{2}{*}{ Petroleum Geoscience } & \multirow[t]{2}{*}{ PG } & \multirow[t]{2}{*}{1995 to current } & PG online-only & f344 & f344 & $\$ 688$ \\
\hline & & & PG online + print & f378 & f378 & $\$ 756$ \\
\hline \multirow[t]{2}{*}{ Scottish Journal of Geology } & \multirow[t]{2}{*}{ SJG } & \multirow[t]{2}{*}{1965 to current } & SJG online-only & f191 & f191 & $\$ 381$ \\
\hline & & & SJG online + print & $f 210$ & f210 & $\$ 419$ \\
\hline \multirow{2}{*}{$\begin{array}{l}\text { Proceedings of the Yorkshire } \\
\text { Geological Society }\end{array}$} & \multirow[t]{2}{*}{ PYGS } & \multirow[t]{2}{*}{1837 to current } & PYGS online-only & f155 & f155 & $\$ 309$ \\
\hline & & & PYGS online + print & f170 & $\mathbf{f 1 7 0}$ & $\$ 340$ \\
\hline \multirow[t]{2}{*}{ Journal of Micropalaeontology } & \multirow[t]{2}{*}{$\mathrm{JM}$} & \multirow[t]{2}{*}{1991 to current } & JM online-only & f175 & f175 & $\$ 350$ \\
\hline & & & JM online + print & f193 & f193 & $\$ 385$ \\
\hline
\end{tabular}

*VAT rate as applicable at the time of invoicing - please see http://www.geolsoc.org.uk/lyellcollection/lcprices for current VAT rates for UK and EU subscribers. **for online only subscribers to Lyell Collection Complete, a complete set of 2011 print copies of the Special Publications can be provided for $\mathrm{f} 200 / U S \$ 400$ for the 2011 subscription year. Prices are for single sites only. Please apply for multi-site and consortial pricing.

To order the Lyell Collection or individual journal titles, or request further information or a free trial, please contact:

In UK and Europe: Email: geologicalsociety@accucoms.com Telephone: +31 715247630

In Korea and Japan: Email: hanalee@ebsco.com Telephone: 82-2-598-2571 (ext. 230)

In USA and Canada: Email: geologicalsociety@pcgpluscom Telephone: +16173954065

In Taiwan, Hong Kong, Macau, SE Asia: Email: salestw@ebsco.com Telephone: +886 287860601

In Australian and New Zealand: Email: dviollet@ebsco.com Telephone: +61 7 5453-7675 All other regions: Email: sales@geolsoc.org.uk Telephone: +44 (0)1225 445046 